УДК 636.4.082 DOI 10.31210/visnyk2018.03.18

(C) 2018

Коробка А. В., Рак Т. М., кандидати сільськогосподарських наук

Полтавська державна аграрна академія

Бітлян О. К., кандидат сільськогосподарських наук,

Конкс Т. М., молодший науковий співробітник

Інститут свинарства і агропромислового виробництва НААН

\title{
ТЕХНОЛОГІЯ ЗАСТОСУВАННЯ ПРЕМІКСІВ РІЗНОГО СКЛАДУ У СВИНАРСТВІ
}

\section{Рецензент - доктор сільськогосподарських наук А. А. Поліщук}

Дослідження присвячено технологічному обтрунтуванню дочільності дозованого використання у годівлі свиней преміксів, до складу яких входять солі різної хімічної природи. Теоретично обгрунтовано й експериментально доведено індиферентний вплив солей мікроелементів різної хімічної природи при їх моновикористанні у складі преміксу «КС-5» на продуктивність тварин. Отримані результати проведених досліджень дали змогу зробити висновки, щчо оптимальним рівнем введення преміксу до складу раціону є рівень 2,0\%, щуо підтверджується витратами корму на 1 кг приросту живої маси, які в иій групі склали 3,9 корм. од., проти контролю-4,3 корм. од. Застосування преміксів, які в свосму складі мають різні форми мікроелементів, особливо з вуглекислих солей, позитивно вплинуло на ріст і розвиток молодняку та підвищцили рентабельність виробниц̧тва свинини.

Ключові слова: премікс, мікро- та макроелементи, раціон, концентрація преміксів, хелатні сполуки, годівля, свинопоголів'я.

Постановка проблеми. 3 точки зору економічного обгрунтування ведення свинарства в ринкових умовах інтенсифікація галузі передбачає, в першу чергу, забезпечення тварин повноцінною годівлею. Одним із шляхів вирішення цього $\epsilon$ застосування різних форм солей мікроелементів у складі преміксів. На даний час накопичено значні експериментальні і практичні дані щодо ефективності застосування солей мікроелементів різної хімічної природи у технології годівлі, зокрема хелатних сполук, задля підвищення продуктивних показників свинопоголів'я $[8,9]$. Проте технологічні засади застосування преміксів, до складу яких входять солі мікроелементів різної природи, в тому числі у вигляді хелатів, їх дозування вивчені недостатньо, що стримує ефективне використання їх у годівлі свиней. Отже, дослідження зазначених проблем $\epsilon$ актуальними i своєчасними у ринкових умовах ведення свинарства.

Аналіз останніх досліджень і публікацій, у яких започатковано розв'язання проблеми.
Для збагачення кормів необхідними мікроелементами сьогодні використовують різні добавки біогенного та небіогенного походження [11]. Введення таких добавок для збагачення раціону дозволяє не лише поповнити потребу організму, а й, підібравши необхідно комплексні поєднання, посилити їх дію та прискорити обмінні процеси у тварин, поліпшити процеси травлення, підвищити конверсію корму та рівень середньодобових приростів, покращити якість виробленої продукції свинарства, зменшити рівень технологічного відходу внаслідок виникнення неінфекційних захворювань i, зменшивши собівартість 1 кг виробленої продукції, підвищити рентабельність та прибутковість ведення галузі [5].

Багаторічний досвід використання повноцінних комбікормів 3 преміксами у свинарстві переконливо свідчить про їх високу ефективність: витрати кормів на центнер приросту живої маси зменшуються до 6-6,5 ц. корм. од.; середньодобовий приріст живої маси на відгодівлі складає не менше 550-600 г; молодняк набуває стійкості проти захворювань [2].

У вирішенні проблем забезпечення повноцінної годівлі тварин в останні роки досягнуто значних успіхів. Використання комбікормів у свинарстві досліджували вітчизняні та зарубіжні вчені $[1,6,7,12,13]$. Питаннями мінерального живлення сільськогосподарських тварин займались вчені В. І. Георгієвський; Б. Д. Кальницький; В.А.Кокорєв, С. Терещенко; В. Е. Чумаченко; М. S. Edmonds; B. E. Arentson; M. E. Ensminger; I. E. Ildffild; S. Hassan; I. D. Pagon; P. Kanezos та інші. Використання комбікормів у сучасних технологіях виробництва свинини при створенні інтенсивних умов утримання тварин змушують науковців та виробничників звертати особливу увагу на питання збалансованості раціонів для годівлі свиней шляхом введення до їх складу солей різних мікроелементів та біологічно активних речовин $[3,4,10]$.

Мета досліджень. Метою роботи $\epsilon$ технологічне обгрунтування доцільності та ефективності використання у годівлі свиней різних доз преміксів та со- 


\section{СІЛЬСЬКЕ ГОСПОДАРСТВО. ТВАРИННИЦТВО}

лей мікроелементів різної хімічної природи.

Завдання досліджень - експериментально обгрунтувати продуктивну дію солей мікроелементів різної природи та концентрації преміксів у годівлі свинопоголів'я; вивчити вплив різної концентрації преміксів у складі раціонів на продуктивність молодняку свиней; визначити економічну ефективність використання різних форм преміксів у годівлі свиней.

Матеріали і методи досліджень. Дослідження проведено в Інституті свинарства і АПВ НААН на молодняку свиней великої білої породи. На першому етапі відповідно до методики постановки науково-господарських дослідів були відібрані тварини аналоги за віком, живою масою, походженням, рівнем розвитку, здоров'ям і конституцією. Контрольна група отримувала основний раціон (ОР), який складався 3 дерті кукурудзи, ячменю і пшениці (у рівних долях), висівок, рибного борошна та преміксу «КС5» у кількості $1 \%$. До раціону свиней першої дослідної групи вводили зазначений премікс у кількості 0,5\%, другої - у кількості 2 \% преміксу, третьої - 5 \% преміксу з одночасним пропорційним зменшенням (збільшенням) борошна люцерни; зменшенням рибного борошна.

На другому етапі були проведені дослідження порівняльного ефекту преміксів із включенням різних форм мікроелементів (табл. 1).

Для вирішення поставлених завдань були використані загальноприйняті зоотехнічні і статистичні методики досліджень.
Результати досліджень. Одержані результати показників росту та споживання кормів молодняком свиней 3 включенням 1,0; 0,5; 2,0 та 5,0 \% преміксу «КС-5» до складу господарського раціону засвідчили позитивний їх вплив на ріст $\mathrm{i}$ розвиток тварин. За показниками динаміки приросту живої маси, середньодобових приростів, абсолютного та відносного приростів найкращі результати одержано у групі відгодівельного молодняку свиней, які отримували у складі раціону 2,0 \% преміксу, зокрема у них середньодобовий приріст склав 434,5 г, що перевищувало даний показник в контрольній групі на 75,5 г. При цьому не одержано очікуваного значного зростання продуктивності молодняку в групі, що отримувала 5,0 \% преміксу, середньодобовий приріст в ній склав 421,5 г (табл. 2). Оптимальним рівнем введення преміксу до складу раціону у наших дослідженнях було на рівні 2,0\%, що підтверджується витратами корму на 1 кг приросту живої маси, які в цій групі склали 3,9 корм. од., проти контролю - 4,3 корм. од. При введенні інших доз преміксу було отримано проміжні дані витрати корму на 1 кг приросту живої маси. У процесі виробничої апробації ефективності одноосібного використання солей мікроелементів у складі преміксу «КС-5» встановлено динамічні зміни живої маси у тварин дослідних груп, що свідчить про стабільність позитивного впливу окремих форм солей мікроелементів у складі преміксів порівняно $з$ стандартним складом рецепту (рис. 1).

\section{1. Схема другого досліду}

\begin{tabular}{|c|c|l|}
\hline Група & $\begin{array}{c}\text { Кількість } \\
\text { свиней, } \\
\text { гол. }\end{array}$ & \multicolumn{1}{|c|}{ Характеристики годівлі } \\
\hline 1 контрольна & 50 & $\begin{array}{l}\text { ОР 3 включенням 2\% преміксу, до складу якого введено сірчанокислі, } \\
\text { хлористі та вуглекислі солі мікроелементів }\end{array}$ \\
\hline 2 дослідна & 50 & $\begin{array}{l}\text { ОР 3 включенням 2 \% преміксу, до складу якого введено тільки } \\
\text { сірчанокислі солі мікроелементів }\end{array}$ \\
\hline 3 дослідна & 50 & $\begin{array}{l}\text { ОР 3 включенням 2 \% преміксу, до складу якого введено тільки } \\
\text { вуглекислі солі мікроелементів }\end{array}$ \\
\hline 4 дослідна & 50 & $\begin{array}{l}\text { ОР з включенням 2\% преміксу, до складу якого введено лише хелатні } \\
\text { форми мікроелементів }\end{array}$ \\
\hline
\end{tabular}

2. Середньодобовий приріст жсивӧ маси молодняка свиней, (n=50)

\begin{tabular}{|c|c|c|c|}
\hline \multirow{2}{*}{ Групи } & \multicolumn{3}{|c|}{ Вік, міс. } \\
\cline { 2 - 4 } & 3 & 4 & у середньому за період \\
\hline 1 контрольна & $250 \pm 9,8$ & $470 \pm 8,5$ & $360,0 \pm 3,11$ \\
\hline 2 дослідна & $303 \pm 2,1$ & $530 \pm 1,7$ & $416,5 \pm 3,09$ \\
\hline 3 дослідна & $336 \pm 8,6$ & $533 \pm 3,8$ & $434,5 \pm 3,15$ \\
\hline 4 дослідна & $343 \pm 7,5$ & $500 \pm 7,8$ & $421,5 \pm 3,00$ \\
\hline \hline
\end{tabular}




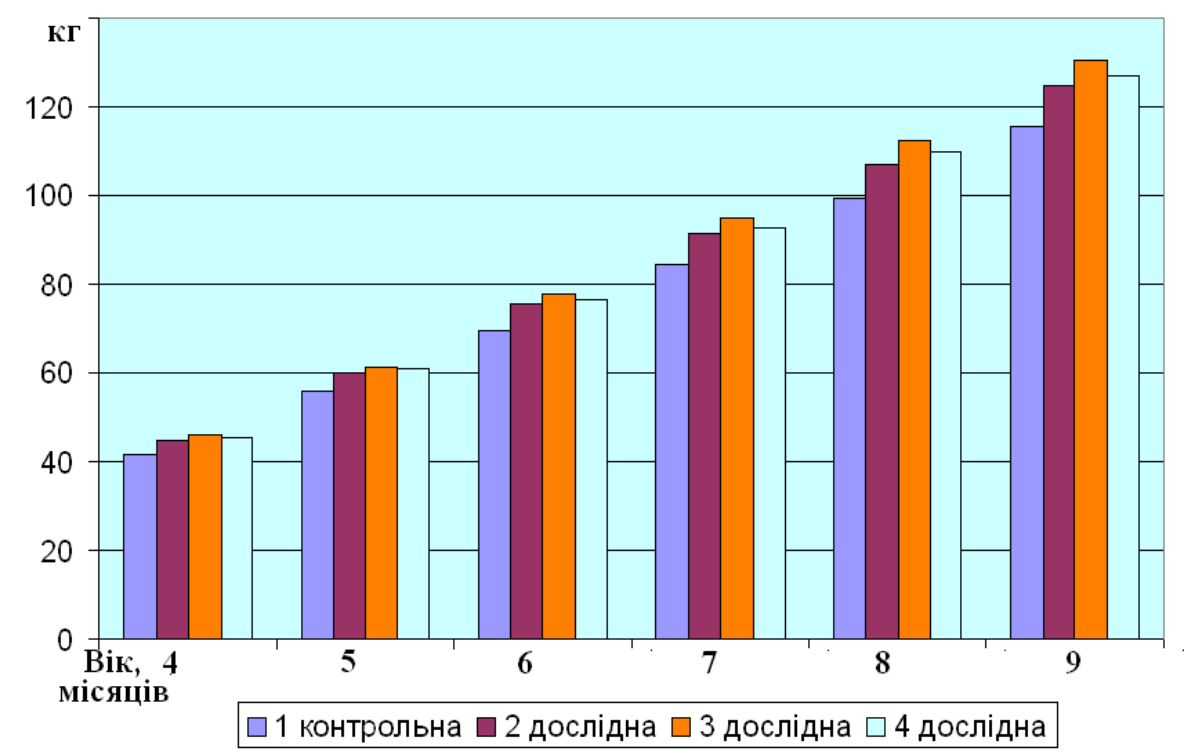

Рис. 1. Динаміка зміни живої маси свиней на відгодівлі, к2 (n=50)

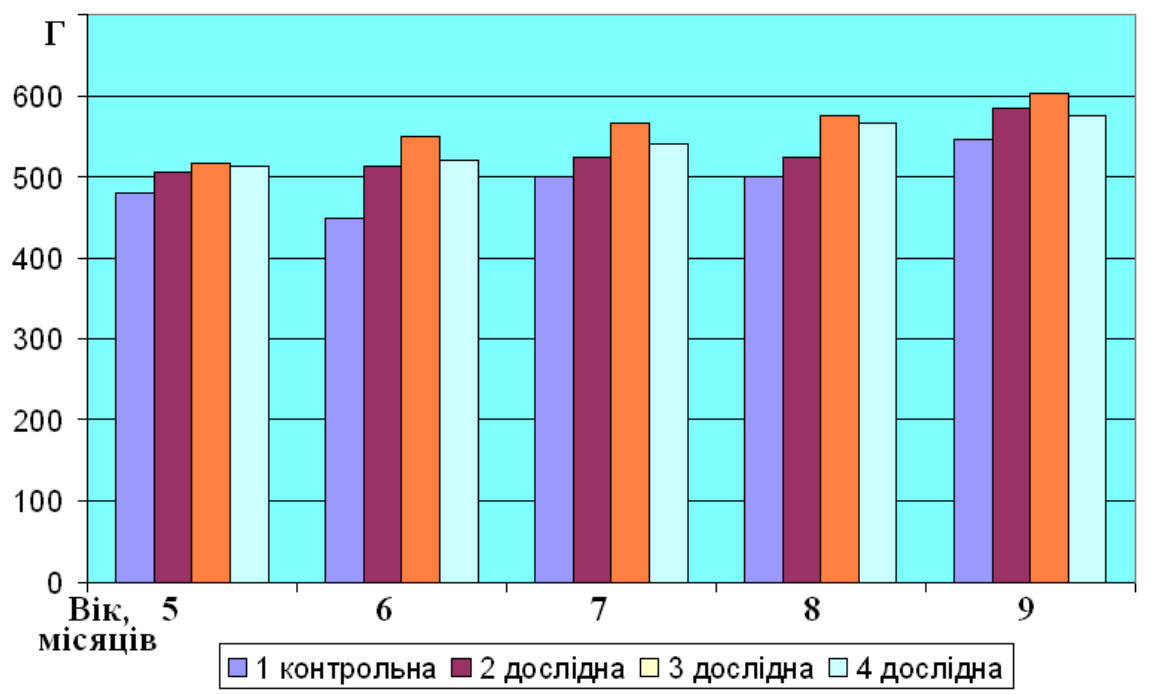

Рис. 2. Динаміка зміни середньодобового приросту свиней на відгодівлі, г (n=50)

Як видно з наведеного графіка, тварини дослідних груп у всіх випадках мали перевагу над тваринами контрольної групи. Тварини четвертої групи мали динаміку зміни живої маси кращу, ніж тварини другої, але гіршу, ніж тварини третьої групи, яка мала самі високі показники зміни, але в абсолютному вимірі відмінності між показниками значень у різних груп невірогідні.

Можна відмітити, що у всі вікові періоди тварини контрольної групи мали найнижчі середньодобові прирости у межах 480-547 г. Тварини четвертої групи хоча, здебільшого, переважали за середньодобовими приростами тварин другої групи, але поступалися тваринам третьої, показ- ники якої мали найвищі значення (516-603 г) у всі вікові періоди (рис. 2).

Таким чином, можна зробити висновок, що введення вуглекислих солей мікроелементів у основний раціон мало найбільш сприятливий вплив на ріст та розвиток відгодівельного поголів'я. Дещо меншим ефектом супроводжувалось введення хелатних форм, а одночасне введення сірчанокислих, хлористих та вуглекислих солей, хоча і мало позитивний вплив, але він був помітно нижчим, ніж після введення вуглекислих та хелатних форм солей.

Узагальнені результати виробничого дослідження наведено в табл. 3 
СІЛЬСЬКЕ ГОСПОДАРСТВО. ТВАРИННИЦТВО

3. Результати виробничої апробації науково-господарського досліду

\begin{tabular}{|c|c|c|c|c|}
\hline \multirow{2}{*}{ Найменування показника } & \multicolumn{4}{|c|}{ Групи } \\
\cline { 2 - 4 } & $\begin{array}{c}\text { I } \\
\text { контрольна }\end{array}$ & $\begin{array}{c}\text { II } \\
\text { дослідна }\end{array}$ & $\begin{array}{c}\text { III } \\
\text { дослідна }\end{array}$ & $\begin{array}{c}\text { IV } \\
\text { дослідна }\end{array}$ \\
\hline Кількість тварин, гол. & 50 & 50 & 50 & 50 \\
\hline Жива маса в 4 міс., кг & 40,6 & 40,0 & 40,2 & 40,0 \\
\hline Жива маса в 9 міс., кг & 110,5 & 123,0 & 129,0 & 126,0 \\
\hline $\begin{array}{c}\text { Абсолютний приріст, за увесь період, } \\
\text { на поголів'я, тонн }\end{array}$ & 2,1 & 4,1 & 4,4 & 4,3 \\
\hline
\end{tabular}

Вищенаведені дані свідчать, що дослідні тварини, отримуючи різні за мінеральним походженням солі мікроелементів, перевищують живу масу свиней контрольної групи. Така різниця в середньодобових приростах живої маси є достатньою умовою для стверджування про позитивний вплив досліджуваних форм солей мікроелементів у складі господарських раціонів, що підтверджуються зростанням абсолютного приросту у тварин дослідних груп без будь-яких відхилень у їх розвитку.

Зважаючи на зростаючу активність використання хелатних сполук у годівлі сільськогосподарських тварин, зазначимо про їх позитивний вплив на ріст, розвиток та продуктивні показники свиней поряд 3 традиційними формами солей мікроелементів комбікормового виробництва. Одержані власні результати не протирічать результатам досліджень ряду науковців у цьому напрямі (В. С. Зернов, 1992 р.; М. О.Захаренко та ін., 2004 р.; В. В. Сенечин, 2004 р.; М. В. Фоміна, 2008 р.; Л. М. Кузьменко та ін., 2011 р.). Це дає підстави стверджувати, що вплив цих сполук на організм тварин відрізняється від дії неорганічних солей, а за біологічною доступністю близький до природних біокомплексів.

У контексті цього, найкращою оплатою корму характеризувалися тварини, раціон яких було збагачено преміксом з вуглекислими солями мікроелементів: витрати корму на 1 кг приросту

\section{БІБЛІОГРАФІЯ}

1. Богданов $Г$. А. Справочник по кормам и кормовым добавкам / Г. А. Богданов, А. И. Зверев, Л. С. Прокопенко, О. Е. Привало. - К. : Урожай, 1984. - С. 17.

2. Дьяченко Л. С. Роль місцевих сировинних ресурсів в енергозберігаючих технологіях виробництва кормів для корів / Л. С. Дьяченко, Г. Л. Сивик // Наук. техн. бюлетень. Інститут тваринництва УААН. - Вип. 78. - Київ, 2000. C. 25-27.

3. Егоров Б. В. Проблемы развития комбикор- живої маси склали 5,89 корм. од.; в контрольній групі - 7,06 корм. од.; в групах, що отримували премікс з сірчанокислими солями мікроелементів та хелатними формами мікроелементів (лізинати), відповідно, 6,26 і 6,17 корм. од.

Результати виробничої апробації попередніх досліджень впливу на продуктивні показники свинопоголів'я різних форм солей мікроелементів в окремому використанні у складі господарських раціонів засвідчили про їх вірогідний позитивний вплив, що підтверджується даними економічної ефективності їх застосування. На дорощуванні молодняку рівень рентабельності в дослідних групах коливався в межах 17,0-20,0 \%, а контрольній - 8,5\%.

Висновок. Одержані результати свідчать, що оптимальним рівнем введення преміксу до складу раціону є рівень 2,0\%, що підтверджується витратами корму на 1 кг приросту живої маси, які в цій групі склали 3,9 корм. од. проти контролю - 4,3 корм. од.

Застосування преміксів, які в своєму складі мають різні форми мікроелементів, особливо 3 вуглекислих солей, позитивно вплинули на ріст і розвиток молодняку та підвищили рентабельності виробництва свинини.

Подальші дослідження будуть спрямовані на вивчення впливу різної концентрації преміксів на фізіологічний стан організму свиней.

мовой промышленности Украины / Б. В. Егоров // Хранение и переработка зерна. - 2000. - № 11. - C. 9-11.

4. Егоров Б. В. Совершенствование технологий подготовки комплексных наполнителей премиксов / Б. В. Егоров // Зернові продукти і комбікорми. -2002 . - № 1. - С. 45-47.

5. Исаева Ю. В. Ферментный препарат «Натуфос» как средство стимуляции обменных процессов в организме поросят отставших в росте / Ю. В. Исаева // Фундаментальные и прикладные 
проблемы повышения продуктивности с.-х. животных изменившихся условиях системы хозяйствования и экологии. Ульяновская гос. с.-х. акад. - Ульяновск, 2005. - Т. 2. - С. 210.

6. Кабанов В. Д. Интенсивное производство свинины / В. Д. Кабанов. - М. : Учебное пособие, 2003. -400 с.

7. Кавардаков В.Я. Кормление свиней / В. Я. Кавардаков, А. И. Баранников, А. Ф. Кайдалов. - Ростов-на-Дону, 2005. - 517 с.

8. Кіщуак I. T. Введення мікроелементів в раціон свиней підвищує їх продуктивність / I. Т. Кіщак, В. М. Бугаєвський, М. О. Шанявський // Інтеграція науки 3 виробництвом - головний шлях збільшення збору сільськогосподарської продукції, зниження затрат при іiі виробництві: наук. праці МДСГДС. - Миколаїв, 1997. - С. 209.

9. Кокорев В. А. Биологическое обоснование потребности супоросных свиноматок в макроэлементах: монография / В. А. Кокорев. - Саранск : Издательство Саратовского университета. Саранский филиал, 1990. - 192 с.

10. Онищенко $A$. О. Вивчення впливу дії різної

\section{ANNOTATION}

Korobka A. V., Rak T. M., Bitlian O. K., Konks T. M. Technology of application of premixs of different composition in pig breeding.

From the point of view of economic substantiation of pig breeding in market conditions, the intensification of the industry implies, first of all, the provision of adequate feeding for animals. One of the solutions to this is the use of different forms of trace elements of trace elements in premixes. At present, considerable experimental and practical data on the effectiveness of the use of salts of trace elements of various chemical nature in feed technology, in particular chelated compounds, have been accumulated on the productive indices of the pork colony. However, the technological principles of the use of premixes, which consist of salts of trace elements of various nature, including chelates, have not been studied sufficiently, which impedes the effective use of them in feeding pigs. Consequently, the study of these problems is relevant and timely in the market conditions for pig breeding. концентрації преміксів на ріст і розвиток молодняку свиней / А. О. Онищенко, О. К. Бітлян // Свинарство. Міжвід. темат. наук. зб. - Полтава, 2014. - Вип. 65. - С. 239м243.

11. Чорнолата Л. П. Перетравність, засвоєння поживних i мінеральних речовин, продуктивність та якість продукції у свиней при згодовуванні мікроелементних добавок // дис. ... канд. с.-г. наук за спец. 06.02.02. - годівля тварин i технологія кормів. - Львівська державна академія ветеринарної медицини ім. С. З. Гжицького. - Львів, 2000.

12. Heyer $A$. Compensatory growth response in pigs: effects on growth performance, composition of weight gain at carcass and muscle levels, and meat quality / Heyer A. and Lebret B. // Journal of Animal Science. - 2007. - Vol. 85. - P. 769-778.

13. Robinson $D$. $W$. Food intake regulation in pigs. The influence of dietary threonine imbalance on food intake, dietary choice and plasma acid patterns / D. W. Robinson // Brit. Vet. J. - 1975. - Vol. 131. - pp. 595-600.

The research is devoted to the technological substantiation of the expediency of dosage in feeding pigs of premixes, which include salts of different chemical nature. The indifferent influence of salts of trace elements of different chemical nature during their mono use in the composition of pre-KS-5 on animal productivity is proved theoretically and experimentally. The general results of the conducted studies allowed to reach the conclusion that the optimum level of introduction of premix into the diet is $2.0 \%$, which is confirmed by the consumption of feed per $1 \mathrm{~kg}$ of live weight gain, which in this group was 5.0 feed op., against control -5.9 pounds unit The use of premixes, which in their composition have different forms of trace elements, especially carbonic salts, have positively influenced the growth and development of young, and increased the profitability of pork production.

Key words: premix, micro and macro elements, diet, concentration of premixes, chelating compounds, feeding, pork neck. 